\title{
Pan-RAF Kinase Inhibitor CCT3833
}

National Cancer Institute

\section{Source}

National Cancer Institute. pan-RAF Kinase Inhibitor CCT3833. NCI Thesaurus. Code C121952.

An orally available inhibitor of the serine/threonine protein kinase family Raf, including ARaf, B-Raf and C-Raf, with potential antineoplastic activity. Upon administration, pan-RAF kinase inhibitor CCT 3833 inhibits Raf-mediated signal transduction pathways, which may inhibit the proliferation of Raf-overexpressing tumor cells. Raf protein kinases play a key role in the RAF/mitogen-activated protein kinase kinase (MEK)/extracellular signalregulated kinase (ERK) signaling pathway, which is often dysregulated in human cancers and plays a key role in tumor cell proliferation and survival. 